\title{
ACADEMICIAN ABID SADYKOVICH SADYKOV
}

From the editors:

The present issue opens with a review paper devoted to the legacy of Academician A. S. Sadykov, and in the following issue we shall publish scientific papers of his colleagues from the Institute of Bioorganic Chemisty and Tashkent State University.

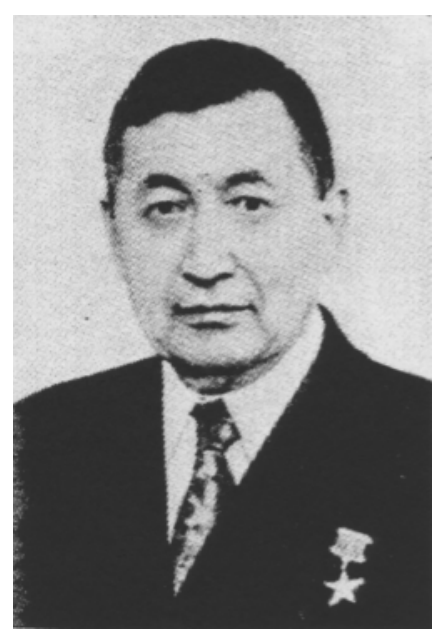

\section{ACADEMICIAN ABID SADYKOVICH SADYKOV}

1913-1987

In November, 1993, the scientific community of Uzbekistan marked the 80th anniversary of the birth of the outstanding chemist Academician Abid Sadykovich Sadykov.

A. S. Sadykov began his scientific activity with a study of the alkaloids of the flora of Central Asia. His work in the field of the chemistry of natural compounds and, in particular, the chemistry of the cotton plant, which has been marked by the D. I. Mendeleev Gold Medal, has become classic.

Abid Sadykovich succeeding in combining the excellent traditions of classical organic chemistry with new scientific directions. He was one of the first to use modern physicochemical and theoretical methods in the practice of the study of natural compounds.

With all his strength, A. S. Sadykov promoted the formation of groups with a command of methods of quantum chemistry, conformational analysis, mathematical calculation, and genetic and cell engineering. He always, on his own part and on the part of his pupils, aimed to bring ideas idea to practical perfection.

In his scientific investigations, A. S. Sadykov closely approached the solution of the problem of the interrelationship of the structure of organic substances and their functions and biological action in plant and animal organisms. And it is not fortuitious that it was Uzbekistan that became the acknowledged center of bioorganic chemistry and that the first International Symposium on Bioorganic Chemistry and Molecular Biology was held in Tashkent.

The Institute of Organic Chemistry created by Abid Sadykovich bears his name. His students are continuing and developing the life's work of this outstanding research worker and human being.

Translated from Khimiya Prirodnykh Soedinenii, No. 6, p. 779, November-December, 1993. 